\title{
Exchange of Total Carbohydrate, Minerals, and Phenolics in Grape and Grape Products
}

\author{
Özlem Aras Așcl ${ }^{1, a, *}$, Nilgün Göktürk Baydar ${ }^{2, b}$ \\ ${ }^{1}$ Pharmacy Services Program, Gelendost Vocational School, Isparta University of Applied Sciences, 32900 Gelendost, Isparta, Turkey \\ ${ }^{2}$ Department of Agricultural Biotechnology, Faculty of Agriculture, Isparta University of Applied Sciences, 32270 Isparta, Turkey
} *Corresponding author

\begin{tabular}{l|l} 
A R T I C L E I N F O & A B S T R A C T \\
\hline $\begin{array}{l}\text { Research Article } \\
\begin{array}{l}\text { Received : 11/03/2021 } \\
\text { Accepted : 20/04/2021 }\end{array}\end{array} \quad \begin{array}{l}\text { In this study, it was aimed to determine the total carbohydrate (CHO), minerals and phenolic (total } \\
\text { phenolic content, total flavanols, total flavonols, and anthocyanins) of grape and grape products. } \\
\text { For this reason, fresh grapes (Kalecik Karas1, Öküzgözü, Emir, and Narince), raisins (Karadimrit } \\
\text { and Sultani Çekirdeksiz), wines (Kalecik Karas1, Öküzgözü, Emir, and Narince), commercial red } \\
\text { grape juice, molasses, and vinegar were used as research materials. In conclusion, total CHO } \\
\text { contents in the samples were ranged from 0.14 to } 48.37 \mathrm{~g} 100 \mathrm{~g}^{-1} \text {. In terms of the minerals, molasses } \\
\text { was rich in K while the highest contents of P and Fe were found in vinegar. Raisin of Karadimrit } \\
\text { contained the highest Ca content among all the samples tested. Not only total phenolic contents but } \\
\text { also total flavanols, total flavonols, and anthocyanins were altered depending on the sample types } \\
\text { and the varieties. As a result, it was determined that grape and grape products represent a potentially } \\
\text { significant source of CHO, minerals, and phenolic. }\end{array}$ \\
$\begin{array}{l}\text { Keywords: } \\
\text { Grape }\end{array}$
\end{tabular}

Grape

Wine

Molasses

Vinegar

Carbohydrate

ozlemaras@isparta.edu.tr

(iD) http://orcid.org/0000-0002-8940-7514

b@ nilgungbaydar@isparta.edu.tr

http://orcid.org/0000-0002-5482-350X

This work is licensed under Creative Commons Attribution 4.0 International License

\section{Introduction}

Plants and plant products always play a substantial role in human health by satisfying various essential needs ranging from food to medicines (Bhat et al., 2010; Sevindik et al., 2017). Grape mainly evaluated by raisin, table, and wine-making is also one of the most valuable fruit species in the world. In addition to these forms of evaluation, grapes are also used to obtain lots of different products such as molasses, grape juice, and vinegar. Grape and grape products are valuable foods because of their different tastes, nutritive values, and favorable effects on human health (Aras Aşc1, 2020).

Carbohydrate (CHO)'s and minerals play an important role in critical functions such as energy metabolism, neural transmission, muscular activity, bone formation, antioxidant activity; vascular constriction, maintaining normal acid-base balance, osmotic pressure, and normal water balance in human body, normal water balance, and osmotic pressure (Talwar and Srivastava, 2002; Srilakshmi, 2006). Recently, the attention on phenolics significantly increased due to their importance on human health as bioactive compounds having antimutagenic, chemopreventive, anticarcinogenic antioxidant and antimicrobial activities (Nemzer et al., 2020; Mohammed et al., 2019; Mohammed et al., 2020). Apart from the medicinal and pharmaceutical potentials phenolics have also great potential to be used in food, agriculture, and cosmetic industries. Therefore, plants containing high levels of phenolics have a great importance as natural antioxidants and it is well known that grapes are rich in phenolics with a high oxygen radical scavenging capacity (Göktürk Baydar et al., 2011; Antoniolli et al., 2015; Sato et al., 2020; Mohammed et al., 2021).

However, the contents of CHOs, minerals and phenolics in grapes vary depending on whether grapes are fresh or processed (Göktürk Baydar et al., 2011; Kelebek et al., 2013). Although grapes are also known to be rich in CHOs, minerals and phenolics (Kavas, 1990; Kanner et al., 1994; Göktürk Baydar et al., 2011), there is no detailed 
study investigated the contents of $\mathrm{CHO}$, minerals and phenolics in different fresh grapes, raisins and grape products such as wine, molasses, vinegar and grape juice, together. Therefore determination of the chemical composition of grape and grape products plays an important role to create a conscious consumption habit on people's nutrition and health which allows them to make a choice according to their aim and needs. This study was performed with the aim of determining the potential of total $\mathrm{CHO}$, minerals and phenolics of fresh grapes from 4 different wine-making grape varieties (Kalecik Karas1, Öküzgözü, Emir, and Narince), raisins from Karadimrit and Sultani Çekirdeksiz, wines from Kalecik Karası, Öküzgözü, Emir, and Narince, commercial red grape juice, molasses, and vinegar.

\section{Materials and Methods}

\section{Materials}

In this study, fresh grapes and wines of 4 wine-making grape varieties (Kalecik Karası (red), Öküzgözü (red), Emir (white), and Narince (white)), raisins of Sultani Çekirdeksiz (white) and Karadimrit (red), commercial red grape juice, molasses and vinegar without additive were used as materials. Fresh grapes were harvested from Tekirdağ Viticulture Research Institute vineyards, Tekirdağ-Turkey. Different brand names of wines (three brands of each), grape juice (three brands), molasses (two brands) and vinegars (four brands) were purchased from a market in Isparta, Turkey. Before analyses, different brands of all samples were combined in equal volumes.

\section{Determination of Total CHO}

Amounts of total CHOs of grape and grape products were measured by the anthrone method of Praznik et al. (1999). The absorbance of the samples was measured at $540 \mathrm{~nm}$. Also, total CHO amounts were stated as $\mathrm{g} 100 \mathrm{~g}^{-1}$. The data obtained were given as the average of the three measurements.

\section{Determination of Minerals}

Determination of K, P, Ca, Mg and Fe in samples was carried out by Inductively Coupled Plasma-Optical Emission Spectroscopy (ICP-OES). Milestone-Ethos plus 900 microwave system was used for the microwave assisted sample digestion of the samples. For the microwave digestion of the grape and grape products, 0.5 $\mathrm{g}$ of powdered $(<1 \mathrm{~mm})$ samples were put in the teflon beakers. A six mL volume of a fresh composed mixture of $\mathrm{HNO}_{3}-\mathrm{H}_{2} \mathrm{O}_{2}(5: 1, \mathrm{v} / \mathrm{v})$ was added to each teflon beaker. The volume of digested samples was completed to $25 \mathrm{ml}$ $\mathrm{mL}$ with distilled water. The ICP-OES measurements were performed by the Perkin-Elmer Optima 5300 DV ICP-OES instrument under the specification of the operating conditions given in Table 1 . The spectral lines used for the different minerals were as follows: $\mathrm{K}, 766.490 \mathrm{~nm}$; $\mathrm{P}$, $213.617 \mathrm{~nm}$; Ca, $317.933 \mathrm{~nm} ; \mathrm{Mg}, 285.213 \mathrm{~nm}$ and $\mathrm{Fe}$, $238.204 \mathrm{~nm}$. The detection limits were as follows; 0.3378 $\mathrm{mg} \mathrm{L}^{-1}$ for $\mathrm{K}$; $0.0836 \mathrm{mg} \mathrm{L}^{-1}$ for $\mathrm{P}$; $0.0253 \mathrm{mg} \mathrm{L}^{-1}$ for $\mathrm{Ca}$; $0.0003 \mathrm{mg} \mathrm{L}^{-1}$ for $\mathrm{Mg}$ and $0.003 \mathrm{mg} \mathrm{L}^{-1}$ for Fe.

\section{Determination of Phenolics}

For the phenolic determination, samples were prepared with different ways. Raisins and fresh grapes were extracted according to the method of Ojeda et al. (2002) while in liquid samples, phenolic analyses were performed without any particular treatment except dilution and filtration. For this reason, molasses was diluted in water in a ratio of 1:20; vinegar and grape juice in a ratio of 1:6. Wines were dealcoholized in rotary evaporated at $35^{\circ} \mathrm{C}$ in order to separate the alcohol-free fraction rich in phenolics from the ethanol and then diluted to the primary volume with distilled water. Spectrophotometric measurements were performed a UV-Visible spectrophotometer (double beam) of Perkin Elmer.

Total phenolic contents of the samples were detected by the Folin-Ciocalteu colorimetric method (Singleton and Rossi, 1965). Results were calculated from the calibration curve obtained with gallic acid and repeated 3 times. Total phenolic contents were calculated as gallic acid equivalents (mg GAE $\mathrm{g}^{-1}$ for solid samples; $\mathrm{mg} \mathrm{GAE} \mathrm{L}^{-1}$ for liquid samples).

Total flavanols were estimated colorimetrically by the vanillin method of Price et al. (1978). The absorbance of the samples was measured at $500 \mathrm{~nm}$ and total flavanols were expressed as catechin equivalents ( $\mathrm{mg} \mathrm{CE} \mathrm{g}^{-1}$ for solid samples; $\mathrm{mg} \mathrm{CE} \mathrm{L}^{-1}$ for liquid samples).

Total flavonols were detected with Neu's reagent by the method of Dai et al. (1995). The absorbance of the samples was measured at $410 \mathrm{~nm}$ and total flavonols in the samples were expressed as routine equivalents ( $\mathrm{mg} \mathrm{RE} \mathrm{g}^{-1}$ for solid samples; $\mathrm{mg} \mathrm{RE} \mathrm{L}^{-1}$ for liquid samples).

Concentration of anthocyanins was determined only red coloured samples by the $\mathrm{pH}$ differential method as described by Wrostad (1976). Each solution in spectrophotometer was measured at $520 \mathrm{~nm}$ and $700 \mathrm{~nm}$ against blanks of $\mathrm{pH} \quad 1.0$ and 4.5 buffers. Total anthocyanins were expressed in solid samples as $\mathrm{mg}^{-1}$ malvidin-3-glucoside; in liquid samples as $\mathrm{mg} \mathrm{L}^{-1}$ malvidin-3-glucoside. Each determination was carried out three times.

Table 1 Operating conditions of ICP-OES.

\begin{tabular}{l|l}
\hline Parameter & Value \\
\hline RF generator (Plasma Ar-Ar) & $40 \mathrm{MHz}$ \\
RF incident power & $1450 \mathrm{~W}$ \\
Viewing mode & Axial for Fe, Mg, Zn; \\
Auxiliary argon flow rate & radial for K, P, Ca \\
Nebulizer argon flow rate & $0.2 \mathrm{~L} \mathrm{~min}^{-1}$ \\
Plasma gas flow rate & $0.55 \mathrm{~L} \mathrm{~min}^{-1}$ \\
\hline Sample uptake flow rate & $17 \mathrm{Lin}^{-1}$ \\
\hline
\end{tabular}

\section{Results and Discussion}

\section{Total CHO Contents of Grape and Grape Products}

CHOs supplying energy to the body are essential substances on human health. CHOs are needed for the proper functioning of the brain, central nervous system, kidneys, and muscles (Srilakshmi, 2006; Gluba-Brzózka et al., 2017; Watson et al., 2021). In this study, total CHO contents of the grape and grape products are given in Table 2. Sample type seems to be an important factor for the 
amounts of CHOs. Total CHO contents varied from 8.01 to

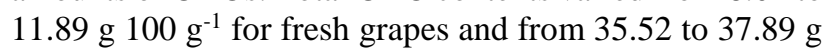
$100 \mathrm{~g}^{-1}$ for raisins. Çetin et al. (2012) determined that total

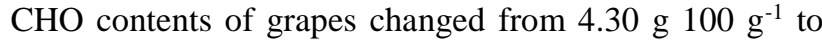

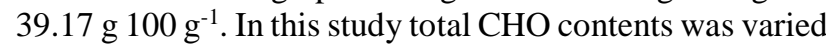
depending on the grape varieties and the color of berries as reported before by Özden and Vardin (2009). The amounts of total $\mathrm{CHO}$ in the grapes of Alphonse Lavallée grape

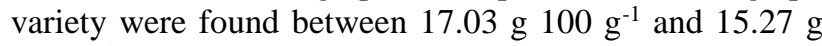
$100 \mathrm{~g}^{-1}$ in different harvest-year (Babalık et al., 2020). Among solid samples, raisins clearly showed higher values of total CHO compared to the fresh grapes. It is an expected result because of the different water contents between fresh grapes and raisins. As regards the liquid samples, the highest total $\mathrm{CHO}$ content was detected in molasses with

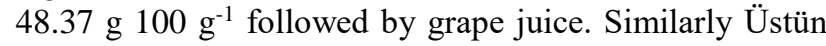
and Tosun (1997) determined that CHO contents of 11

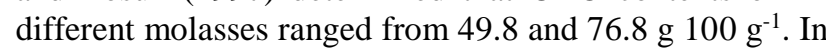
another study conducted on CHO contents of molasses (Elmac1 and Altug, 1993) total CHO contents of different

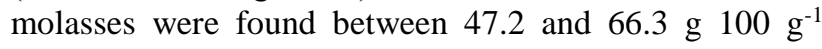
according to the maturity, agricultural applications, climatic conditions and processing techniques. Total $\mathrm{CHO}$ contents of wines varied from 0.14 to $0.36 \mathrm{mg} 100 \mathrm{~g}^{-1}$ and it was noted that white wines have more $\mathrm{CHO}$ than red wines. Rovio et al. (2011) reported that Pinot Noir red wine varied between $1.45-1.90 \mathrm{~g} \mathrm{~L}^{-1}$ in their study on the total CHO amounts.

\section{Mineral Contents of Grape and Grape Products}

The plant materials rich in nutrient minerals play an effective role in human health when consumed in recommended amounts. Minerals generally comprise from $0.2 \%$ to $0.6 \%$ of the fresh weight of the fruits (Dharmadhikari, 2010). In this study, it was determined that grapes and grape products contained nutrient minerals such as $\mathrm{K}, \mathrm{P}, \mathrm{Ca}, \mathrm{Mg}$ and $\mathrm{Fe}$ at different levels depending on the grape varieties and the sample types (Table 3 ). $\mathrm{K}$ is an extremely important mineral for health because it helps your cells to function properly, reduces blood pressure and risks for cardiovascular disease and stroke (Clegg et al., 2020). In addition, by increasing $\mathrm{Ca}$ intake, it reduces calcium loss and prevents osteoporosis (Dawson-Hughes et al., 2009). K also plays a substantial role in berry development and wine quality (Martins et al., 2012). As shown in Table 3, molasses had the highest levels of $\mathrm{K}$ (974.40 mg $100 \mathrm{~g}^{-1)}$ whereas grape juice had the lowest (76.70 mg $100 \mathrm{~g}^{-1}$ ). K contents of the samples were following order: molasses $>$ Kalecik Karası wine > Öküzgözü wine $>$ Karadimrit raisin $>$ Sultani Çekirdeksiz raisin $>$ Narince wine $>$ Emir wine $>$ vinegar $>$ Emir fresh grape $>$ Kalecik Karası fresh grape $>$ Narince fresh grapes $>$ Öküzgözü fresh grape $>$ grape juice. In this study, K contents in fresh grapes were found between $244.10 \mathrm{mg}$ $100 \mathrm{~g}^{-1}$ and $317.90 \mathrm{mg} 100 \mathrm{~g}^{-1}$. Similarly K contents in Chardonnay and Merlot grape varieties were found as

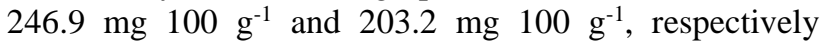
(Pereira et al., 2006; Bertoldi et al., 2011). Kavas (1990) reported that $\mathrm{K}$ was found in fresh grape as 40-260 mg 100 $\mathrm{g}^{-1}$; in molasses as $1470 \mathrm{mg} 100 \mathrm{~g}^{-1}$ and in raisins as 673$869 \mathrm{mg} 100 \mathrm{~g}^{-1}$. As previously reported (Keskin et al., 2019) that $K$ contents in grapes have been showed big variances depending on the genotypes.

$\mathrm{P}$ can be found in nature and plant tissues as phosphates, which are phosphoric acid salt. When it was examined the data about $\mathrm{P}$ contents of the samples, $\mathrm{P}$ content in fresh grapes varied between $9.50 \mathrm{mg} 100 \mathrm{~g}^{-1}$ and $19.30 \mathrm{mg} 100 \mathrm{~g}^{-1}$. Contents of $\mathrm{P}$ in raisins were also determined between 40.20 mg $100 \mathrm{~g}^{-1}$ and $50.50 \mathrm{mg} 100 \mathrm{~g}^{-1}$. Our findings are in agreement with Kavas (1990) stating that P was found in fresh grape as $10-42 \mathrm{mg} 100 \mathrm{~g}^{-1}$ and in raisins as 33-128 mg $100 \mathrm{~g}^{-1}$. Similarly, Keskin et al. (2019) also reported that $\mathrm{P}$ content was found between $15.49 \mathrm{mg} 100 \mathrm{~g}^{-1}$ and $42.18 \mathrm{mg} 100 \mathrm{~g}^{-1}$ in 24 native grape varieties grown in MidBlack Sea Zone. The highest $\mathrm{P}$ content was found in

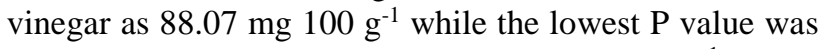
detected from red grape juice with $6.70 \mathrm{mg} 100 \mathrm{~g}^{-1}$ (Table 3 ). On the other hand, P content of molasses was found as

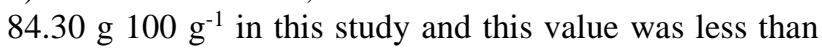
the result reported by Kavas (1990) determining P content

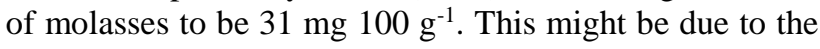
differences among grape varieties, maturity and production technique. Similarly, Üstün and Tosun (1997) also found that molasses contained $\mathrm{P}$ between 0 and $95.06 \mathrm{mg} 100 \mathrm{~g}^{-1}$.

$\mathrm{Ca}$ is the major component of the bones and helps regulate endo- and exo-enzymes. It also plays a significant role in regulating blood pressure and helps to neutralize acids and poisons (Yiğit and Yiğit, 2020). Therefore, it is an essential mineral for the human health. The results from the present study also showed that grape and grape products are rich in $\mathrm{Ca}$. Ca concentrations in solid samples varied from 6.20 (Öküzgözü fresh grape) to $90.50 \mathrm{mg} 100$ $\mathrm{g}^{-1}$ (Karadimrit raisin) and in liquid samples ranging from

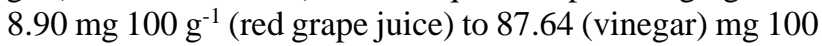
$\mathrm{g}^{-1}$. Kavas (1990) detected Ca in grapes between $4 \mathrm{mg} 100$

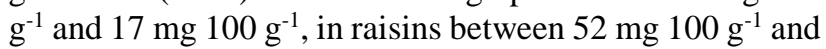

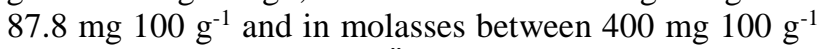
and $500 \mathrm{mg} 100 \mathrm{~g}^{-1}$ while Üstün and Tosun (1997) found 50.9-206.1 mg $100 \mathrm{~g}^{-1}$ of $\mathrm{Ca}$ in molasses, just like our results.

Table 2. Total CHO contents of grape and grape products.

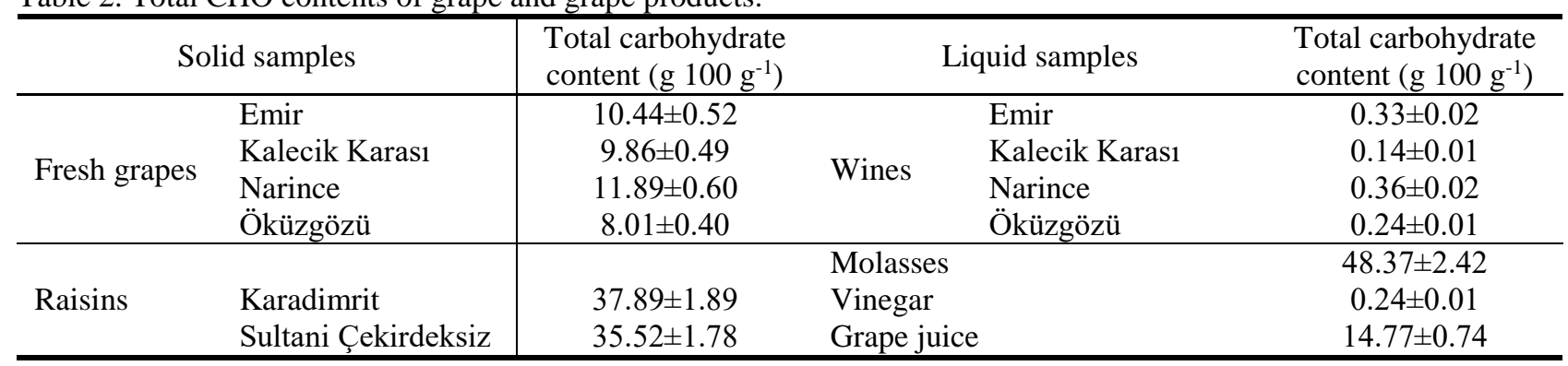


Table 3. Mineral contents of grape and grape products.

\begin{tabular}{|c|c|c|c|c|c|c|}
\hline & & \multicolumn{5}{|c|}{ Contents of minerals $\left(\mathrm{mg} 100 \mathrm{~g}^{-1}\right)$} \\
\hline & & $\mathrm{K}$ & $\mathrm{P}$ & $\mathrm{Ca}$ & $\mathrm{Mg}$ & $\mathrm{Fe}$ \\
\hline \multicolumn{7}{|c|}{ Solid samples } \\
\hline \multirow{4}{*}{$\begin{array}{l}\text { Fresh } \\
\text { grapes }\end{array}$} & Emir & $317.90 \pm 1.20$ & $19.30 \pm 0.10$ & $28.70 \pm 5.40$ & $13.30 \pm 0.10$ & $0.40 \pm 0.00$ \\
\hline & Kalecik Karası & $315.10 \pm 6.20$ & $9.50 \pm 0.10$ & $13.80 \pm 0.10$ & $9.10 \pm 0.20$ & $0.70 \pm 0.01$ \\
\hline & Narince & $277.00 \pm 1.06$ & $16.60 \pm 0.10$ & $20.00 \pm 0.10$ & $10.30 \pm 0.10$ & $0.30 \pm 0.00$ \\
\hline & Öküzgözü & $244.10 \pm 2.48$ & $10.70 \pm 0.10$ & $6.20 \pm 0.10$ & $6.30 \pm 0.01$ & $0.40 \pm 0.01$ \\
\hline \multirow[t]{3}{*}{ Raisins } & Karadimrit & $781.60 \pm 4.20$ & $50.50 \pm 4.30$ & $90.50 \pm 1.20$ & $37.00 \pm 8.30$ & $4.40 \pm 0.05$ \\
\hline & Sultani Çekirdeksiz & $758.50 \pm 11.50$ & $40.20 \pm 0.50$ & $45.70 \pm 2.30$ & $29.80 \pm 2.20$ & $1.00 \pm 0.01$ \\
\hline & & \multicolumn{5}{|c|}{ Liquid samples } \\
\hline \multirow{4}{*}{ Wines } & Emir & $590.40 \pm 2.76$ & $37.12 \pm 1.93$ & $63.98 \pm 0.66$ & $68.14 \pm 0.73$ & $3.46 \pm 0.03$ \\
\hline & Kalecik Karası & $899.60 \pm 2.20$ & $44.54 \pm 0.27$ & $82.22 \pm 0.40$ & $82.60 \pm 0.38$ & $5.20 \pm 0.09$ \\
\hline & Narince & $678.40 \pm 1.82$ & $48.38 \pm 0.65$ & $65.32 \pm 1.07$ & $69.58 \pm 0.94$ & $2.50 \pm 0.03$ \\
\hline & Öküzgözü & $874.20 \pm 9.46$ & $56.24 \pm 0.44$ & $68.22 \pm 0.81$ & $80.26 \pm 0.97$ & $6.39 \pm 0.05$ \\
\hline \multicolumn{2}{|c|}{ Molasses } & $974.40 \pm 7.97$ & $84.30 \pm 9.19$ & $71.10 \pm 0.67$ & $66.70 \pm 2.20$ & $2.30 \pm 0.01$ \\
\hline \multicolumn{2}{|c|}{ Vinegar } & $521.80 \pm 7.80$ & $88.07 \pm 0.97$ & $87.64 \pm 1.31$ & $53.88 \pm 0.87$ & $5.55 \pm 0.06$ \\
\hline \multicolumn{2}{|c|}{ Grape juice } & $76.70 . \pm 0.82$ & $6.70 \pm 0.10$ & $8.90 \pm 0.05$ & $6.00 \pm 0.03$ & $0.10 \pm 0.00$ \\
\hline
\end{tabular}

Magnesium lowers blood pressure, decreases serum triglyceride level and cardiovascular diseases (Zhang et al., 2012; Chiuve et al., 2013). In this study, $\mathrm{Mg}$ concentrations ranged from $6.00 \mathrm{mg} 100 \mathrm{~g}^{-1}$ (grape juice) to $82.60 \mathrm{mg} 100$ $\mathrm{g}^{-1}$ (Kalecik Karası wine). Raisins had more $\mathrm{Mg}$ contents than fresh grapes in the solid samples and wines were rich in $\mathrm{Mg}$ compared to the other liquid samples. It was determined that $\mathrm{Mg}$ contents were changed depending on the sample types and the varieties as reported before (Sousa et al., 2014; Cantürk et al., 2016). In fresh grapes contents of $\mathrm{Mg}$ varied from $6.30 \mathrm{mg} 100 \mathrm{~g}^{-1}$ to $13.30 \mathrm{mg} 100 \mathrm{~g}^{-1}$. Similar to these results Keskin et al. (2019) reported that $\mathrm{Mg}$ contents in grapes varieties varied from $5.93 \mathrm{mg} 100 \mathrm{~g}^{-1}$ to $13.87 \mathrm{mg}$ $100 \mathrm{~g}^{-1}$ in native grape varieties grown in Mid-Black Sea Zone. Panceri et al. (2013) also detected Mg in Cabernet Sauvignon and Merlot grape varieties as 3.860 and $5.08 \mathrm{mg}$ $100 \mathrm{~g}^{-1}$, respectively. Kavas (1990) studying on mineral composition of different grape samples reported that $\mathrm{Mg}$ was found in fresh grapes as 5-20 mg $100 \mathrm{~g}^{-1}$ and in raisins as $35-42 \mathrm{mg} 100 \mathrm{~g}^{-1}$. While these results are similar to our findings, he determined lower $\mathrm{Mg}$ content in molasses as $14 \mathrm{mg} 100 \mathrm{~g}^{-1}$ compared to our results. This difference may be arisen from genotypes, fertilization, soil properties, maturity, and production procedure.

In this study, contents of $\mathrm{Fe}$ in grape and grape products were also examined because of the important effects of FE on human health. Fe-deficiency anemia is one of the most important public health problems of underdeveloped, developing countries. Fe deficiency anemia in a country; it is related to the cultural, socio-economic structure, and development of that country. This trace mineral is an essential of hemoglobin in red blood cells and myoglobin in muscles (Lopez et al., 2016). Fe is also recognized to be potential antioxidant (Talwar and Srivastasa, 2002). Kavas (1990) stated that $\mathrm{Fe}$ in raisin and molasses is absorbed easily by digestive system and these products can satisfy $37 \%$ of daily $\mathrm{Fe}$ requirement. In this study, it was determined that not only sample types but also genotypes seem to be important factors affecting the Fe content. In solid samples, fresh grapes had Fe between 0.30 and 0.70 $\mathrm{mg} 100 \mathrm{~g}^{-1}$ as reported in previous studies (Bertoldi et al., 2011; Sousa et al., 2014; Cantürk et al., 2016) and Fe content changed depending on the grape varieties. Similarly, it was reported that Fe contents in 24 different grape varieties varied from $0.51 \mathrm{mg} 100 \mathrm{~g} \mathrm{~g}^{-1}$ to $2.30 \mathrm{mg} 100$ $\mathrm{g}^{-1}$ (Keskin et al., 2019). In this study, Fe was found in raisins between 1.00 and $4.40 \mathrm{mg} 100 \mathrm{~g}^{-1}$. Raisin of Karadimrit showed 4-fold higher $\mathrm{Fe}$ than did raisin of Sultani Çekirdeksiz. These findings are in agreement with the results of Kavas (1990) determined that fresh grapes had Fe between 0.1 and $0.6 \mathrm{mg} 100 \mathrm{~g}^{-1}$ and raisins had between 1.6 and $3.3 \mathrm{mg} 100 \mathrm{~g}^{-1}$. The highest Fe-containing liquid samples were determined in Öküzgözü wine $(6.32 \mathrm{~g}$ $100 \mathrm{~g}^{-1}$ ) and Kalecik Karası wine (5.50 mg $\left.100 \mathrm{~g}^{-1}\right)$. Some of the interesting results in this study, red grapes and wines had more Fe contents than white ones and wines were rich in compared to the fresh grapes. The amount of mineral substances in wine is very important in their toxic effects and changes in wine quality. Fe content in wines and musts is usually between 0.5 and $20 \mathrm{mg} \mathrm{L}^{-1}$. Even the grapes grown in soils with high iron content are low in Fe levels. If $\mathrm{Fe}$ concentration in wine is above $10 \mathrm{mg} \mathrm{L}^{-1}$, negative situations such as turbidity and color changes are encountered (Garcia Jahres et al., 1990). The cation profile of wine gives us information about the region and conditions in which grapes are grown. Similar to our results, Üstün and Tosun (1997) indicated that Fe contents of wines ranged from 2.62 to $16.30 \mathrm{mg} 100 \mathrm{~g}^{-1}$ depending on the genotypes.

According to the data obtained from the study, grape and grape products are rich in some of the essential minerals including $\mathrm{K}, \mathrm{P}, \mathrm{Ca}, \mathrm{Fe}$ and $\mathrm{Mg}$ and their contents were changed depending on the sample types and the genotypes. Similarly Keskin et al. (2019) found significant variations in the contents of minerals among grape varieties. Since all minerals mentioned above are also effective in performing vital functions in the human body, it is important to include plants with such minerals in our diet. In this context, interest in traditionally consumed plant products due to growth and development, biochemical functions, and beneficial effects on people's basic enzyme systems, has increased (Bhat et al., 2010). 


\section{Phenolic Contents of Grape and Grape Products}

Phenolic compounds are of great importance because of the effects on the color, flavor, bitterness, and astringency in grape and grape products (Burin et al., 2010). Apart from the genetic structure, berry color, ripening stage, cultural practices, climatic conditions and water status are able to impact the levels of phenolics (Koundouras et al., 2006; Orduña, 2010). In this study, total phenolics, total flavanols, total flavonols and anthocyanins were measured as spectrophotometrically. For routine quality control, spectrophotometric methods such as the Folin-Ciocalteu are considered very beneficial because they are low cost, reproducible and quick methods (Vrhovsek et al., 2001). The concentrations of total phenolics obtained from grape and different grape products are illustrated in Table 4. Total phenolic contents in fresh grapes were ranged from 1.87 to $3.42 \mathrm{mg} \mathrm{g}^{-1}$. As regard the fresh grapes, red grapes showed higher phenolic contents than white grapes. In previous studies, it was determined that the total phenolic contents varied significantly depending on the grape varieties and the berry color (Mazza, 1995; Göktürk Baydar, 2006; Yang et al., 2009; Ivanova et al., 2010). The differences among the varieties in terms of total phenolic contents can be affected by the factors such as water content and size of the berry. As a matter of fact, phenolic contents varied according to the ratio between grape skin surface and the berry volume (Champagnol, 1998). Similarly raisin of Karadimrit had more phenolic content compared with the raisin of Sultani Çekirdeksiz, The results showing that red grapes and raisins had more phenolic contents than white ones are in agreement with previous reports from Katalinic et al. (2010) and Göktürk Baydar et al. (2011). Babalık et al. (2020) also reported that total phenolic contents in grapes changed depending on the harvest year and the exogenous applications such as 24-epibrassinolide.

In liquid samples, the highest total phenolic content was determined in molasses $\left(9823.24 \mathrm{mg} \mathrm{L}^{-1}\right)$ followed by red wines. Karakaya et al. (2001) also determined that molasses contained the highest phenolic content among the eleven liquid samples including white wine, red wine, violet carrot juice, Turkish coffee, instant coffee, coke, black tea, linden flower, apricot nectar and sage. Phenolics are important compounds of wines because they contribute to their sensory characteristics including color, astringency, flavor, bitterness and hardness (Hufnagel and Hofmann, 2008; Challacombe et al., 2012). Although the effects of various classes of phenolics have been extensively studied on the quality of wines, only relatively recently these components gained increasing attention as nutritional antioxidants. Because there was a close correlation between antioxidant activities of wines and their phenolic contents (Katalinic et al., 2004; Göktürk Baydar et al., 2011). In this study, the total phenolic contents of wines were found as $1771.35 \mathrm{mg} \mathrm{L}^{-1}$ for Kalecik Karası, $1606.76 \mathrm{mg} \mathrm{L}^{-1}$ for Öküzgözü, $159.63 \mathrm{mg}$ $\mathrm{L}^{-1}$ for Narince and $139.50 \mathrm{mg} \mathrm{\textrm {L } ^ { - 1 }}$ for Emir. The total concentrations of phenolics in red wines were higher than those in white wines; this coincides with the findings described previously (Karakaya et al., 2001; Göktürk Baydar et al., 2011). The importance of phenolic compounds, which have a complex structure, in flavor, color, and stability characteristic in wine and grape juices is well recognized. Phenolic compounds in grape juice and wines are also known to be affected by storage, variety, topographical characteristics, climate, soil. Soleas et al. (1997) found that total phenolic contents were found 1000$4000 \mathrm{mg} \mathrm{L}^{-1}$ in red wines and between 50 and $2000 \mathrm{mg} \mathrm{L}^{-1}$ in white wines. $\mathrm{Li}$ et al. (2009) also detected that the amount of total phenolics averaging $2068 \mathrm{mg} \mathrm{L}^{-1}$, for the red wines and averaging $302 \mathrm{mg} \mathrm{L}^{-1}$, for the white wines. These results are similar to the results of this study. Another result obtained in this research was that vinegar and grape juice had higher total phenolic contents than white wines. It is an anticipated result because vinegar and grape juice obtained from red grape varieties and red grape skin had more phenolic contents compared to the white grape skin (Göktürk Baydar, 2006). In this study, grape juice contained more total phenolic $\left(295.82 \mathrm{mg} \mathrm{L}^{-1}\right)$ than vinegar $\left(233.05 \mathrm{mg} \mathrm{L}^{-1}\right)$ similar to the findings of Davalos et al. (2005). Total phenolic contents of grape juices ranged from 254 to $2246 \mathrm{mg} \mathrm{L}^{-1}$ (Bosanek et al., 1996) while Hallaç Türk et al. (2009) found total phenolic content in vinegar as $198.19 \mathrm{mg} \mathrm{L}^{-1}$. Besides, Alonso et al. (2004) found that the total phenolic content of the vinegar varied between $200 \mathrm{mg} \mathrm{L}^{-1}$ and $1000 \mathrm{mg} \mathrm{L}^{-1}$ depending on the grape varieties and the producer companies. These results are in agreement with our findings.

Table 4. Total phenolic contents of grape and grape products.

\begin{tabular}{|c|c|c|c|c|c|}
\hline & & $\begin{array}{c}\text { Total phenolic } \\
\text { content } \\
\left(\mathrm{mg} \mathrm{GAE} \mathrm{g}^{-1}\right)\end{array}$ & $\begin{array}{c}\text { Total flavanol } \\
\text { content } \\
\left(\mathrm{mg} \mathrm{CE} \mathrm{g}^{-1}\right)\end{array}$ & $\begin{array}{c}\text { Total flavonol } \\
\text { content } \\
\left(\mathrm{mg} \mathrm{RE} \mathrm{g}^{-1}\right)\end{array}$ & $\begin{array}{l}\text { Anthocyanin } \\
\text { content }\left(\mathrm{mg} \mathrm{g}^{-1}\right)\end{array}$ \\
\hline \multicolumn{6}{|c|}{ Solid samples } \\
\hline \multirow{4}{*}{$\begin{array}{l}\text { Fresh } \\
\text { grapes }\end{array}$} & Emir & $1.87 \pm 0.14$ & $0.73 \pm 0.08$ & $0.17 \pm 0.02$ & $-*$ \\
\hline & Kalecik Karası & $3.42 \pm 0.15$ & $2.63 \pm 0.26$ & $0.31 \pm 0.00$ & $0.25 \pm 0.01$ \\
\hline & Narince & $2.22 \pm 0.16$ & $1.05 \pm 0.18$ & $0.31 \pm 0.02$ & - \\
\hline & Öküzgözü & $3.12 \pm 0.19$ & $1.78 \pm 0.16$ & $0.31 \pm 0.01$ & $0.91 \pm 0.05$ \\
\hline \multirow{2}{*}{ Raisins } & Karadimrit & $3.55 \pm 0.49$ & $3.31 \pm 0.24$ & $0.18 \pm 0.00$ & $0.06 \pm 0.00$ \\
\hline & Sultani Çekirdeksiz & $1.45 \pm 0.10$ & $1.09 \pm 0.04$ & $0.15 \pm 0.01$ & - \\
\hline \multicolumn{6}{|c|}{ Liquid samples } \\
\hline \multirow{4}{*}{ Wines } & Emir & $139.50 \pm 19.80$ & $43.84 \pm 0.00$ & $23.85 \pm 3.36$ & - \\
\hline & Kalecik Karası & $1771.35 \pm 35.11$ & $785.49 \pm 33.33$ & $197.55 \pm 7.47$ & $30.02 \pm 1.50$ \\
\hline & Narince & $159.63 \pm 18.35$ & $33.12 \pm 0.00$ & $33.49 \pm 1.61$ & - \\
\hline & Öküzgözü & $1606.76 \pm 38.06$ & $654.50 \pm 45.26$ & $190.79 \pm 5.32$ & $53.07 \pm 2.65$ \\
\hline \multicolumn{2}{|c|}{ Molasses } & $9823.24 \pm 49.18$ & $667.63 \pm 23.12$ & $3115.51 \pm 10.03$ & - \\
\hline \multicolumn{2}{|c|}{ Vinegar } & $233.05 \pm 16.52$ & $133.40 \pm 8.96$ & $5.58 \pm 0.00$ & $1.70 \pm 0.10$ \\
\hline \multicolumn{2}{|c|}{ Grape juice } & $295.82 \pm 8.31$ & $134.01 \pm 7.59$ & $56.40 \pm 6.27$ & $0.15 \pm 0.00$ \\
\hline
\end{tabular}


Flavanols, a subclass of a larger group of flavonoids, are formed by the replacement of the double-bonded oxygen atom in the $\mathrm{C}$ ring in the flavonol structure by the -CH2 group (Spiegel et al., 2020). While polymer forms of flavanols are responsible for the astringency of wine, their monomer forms such as catechin and epicathechin contribute to its bitterness (Ojeda et al., 2002). In this study, total flavanol contents were significantly changed depending on the samples (Table 4). Total flavanol contents in solid samples varied from $0.73 \mathrm{mg} \mathrm{g}^{-1}$ (Emir fresh grape) to $3.31 \mathrm{mg} \mathrm{g}^{-1}$ (Karadimrit raisin). In fresh grapes, total flavanols were found between $0.73 \mathrm{mg} \mathrm{g}^{-1}$ and $2.63 \mathrm{mg} \mathrm{g}^{-1}$. Similarly, total flavanol contents in grapes was found to vary between $0.92 \mathrm{mg} \mathrm{g}^{-1}$ and $1.67 \mathrm{mg} \mathrm{g}^{-1}$ depending on the varieties (Göktürk Baydar et al., 2005). The highest total flavanol contents in liquid samples were found in Kalecik Karası wine (785.49 $\left.\mathrm{mg} \mathrm{L}^{-1}\right)$ followed by molasses (667.63 $\left.\mathrm{mg} \mathrm{L}^{-1}\right)$, Öküzgözü wine (654.50 $\left.\mathrm{mg} \mathrm{L}^{-1}\right)$, grape juice (134.01 $\left.\mathrm{mg} \mathrm{L}^{-1}\right)$, vinegar $\left(133.40 \mathrm{mg} \mathrm{L}^{-1}\right)$, Emir wine (43.84 $\mathrm{mg} \mathrm{L}^{-1}$ ) and Narince wine $\left(33.12 \mathrm{mg} \mathrm{L}^{-1}\right)$, respectively. In a previous study, total flavanol contents of wines were found between 291.1 and $664.8 \mathrm{mg} \mathrm{L}^{-1}$ (Arnous et al., 2002).

Flavonols such as rutin and quercetin are also responsible for the bitter taste in wines (Ojeda et al., 2002) and known to support health by serving as antihistaminic, antiviral, and anti-inflammatory effects (Soleas et al., 1997). In this study, total flavonol amounts of the grape and grape products were given in Table 4. Fresh grapes of Kalecik Karası, Narince and Öküzgözü had equal amounts of total flavonol contents as $0.31 \mathrm{mg} \mathrm{g}^{-1}$ while the lowest value was determined from Emir fresh grape as $0.17 \mathrm{mg} \mathrm{g}^{-1}$. These results were in agreement with the results of Göktürk Baydar et al. (2005) founding total flavonol contents between 0.12 and $0.33 \mathrm{mg} \mathrm{g}^{-1}$ in some grape varieties. Total flavonol contents of liquid samples were ranged from 5.58 $\mathrm{mg} \mathrm{L}^{-1}$ (vinegar) to $3115 \mathrm{mg} \mathrm{L}^{-1}$ (molasses). The data, estimated by analyzing total flavonols in wines, is presented in Table 4 . The results show that red wines contain high concentrations of total flavonols as in total flavanols. Our analysis results show that the content of flavonoids was dependent on the color of the wine. Flavonoids are found mainly in grape skins. In the production of white wine, skin maceration is either absent or done for a very short time. Thus, as expected, white wines contain little or no flavonols (Anlı et al., 2008).

Anthocyanins found high in red grapes and red grape products, are used in natural food additives and pharmaceutical industries with their attractive red colors (Zhang and Furusaki, 1999). Anthocyanins, the most common group of water-soluble plant pigments (Khoo and Falk, 2014), are not found in white grapes (El-Mashharawi et al., 2020). Although they are mainly localized in the berry skin, they are also found in the flesh of some grape varieties called teinture. Anthocyanin contents of the grapes were affected by a number of factors such as variety, cultural practices, girdling and viral infections (Downey et al., 2006; Katalinic et al., 2010). Anthocyanins have been used as natural food dyes in the food industry for many years, and have been reported to have preventive effects on many chronic diseases such as pyrexia, hypertension, liver disorders, diarrhea, urinary problems, and dysentery in terms of benefits to human health (Gil et al., 2000; Konczak and Zhang, 2004).

Anthocyanins contents of red fresh grapes, raisin vinegar and grape juice are illustrated in Table 4. Anthocyanin contents of fresh grapes were found as 0.25 $\mathrm{mg} \mathrm{g}^{-1}$ in Kalecik Karası and as $0.91 \mathrm{mg} \mathrm{g}^{-1}$ in Öküzgözü. Toprak (2011) also reported that the total amount of anthocyanin in Kalecik Karası grapes was determined as $0.32 \mathrm{mg} \mathrm{g}^{-1}$. In previous studies conducted by different researchers, the amount of anthocyanin varied between 0.3 and $7.5 \mathrm{mg} \mathrm{g}^{-1}$ (Mazza, 1995); $0.16 \mathrm{mg} \mathrm{g}^{-1}$ and $1.85 \mathrm{mg} \mathrm{g}^{-1}$ (Katalinic et al., 2010); $0.50 \mathrm{mg} \mathrm{g}^{-1}$ and $4.99 \mathrm{mg} \mathrm{g}^{-1}$ (Balík et al., 2013) depending on the genotypes. Not only genotypes, but also factors such as ecological conditions, maturation levels, cultural processes applied in the vineyard significantly change the amount of anthocyanin in grapes (Ribéreau-Gayon et al., 2000; De La Hera Orts et al., 2005). Similarly, anthocyanin contents in 2 consecutive years were found as $0.42 \mathrm{mg} \mathrm{g}^{-1}$ and $0.49 \mathrm{mg} \mathrm{g}^{-1}$ in Alphonse Lavallée berries (Babalık et al., 2020). It has also been determined by many previous studies that the amount of anthocyanin varies according to the variety. These results are in agreement with our findings. In this study it was also reported that fresh grapes contained more anthocyanins than raisins. This result does agree with the findings of Rababah et al. (2012) studying on the anthocyanin contents of fresh grapes, raisin and jam. In the liquid samples, wines contain anthocyanin between 30.02 $\mathrm{mg} \mathrm{L}^{-1}$ and $53.07 \mathrm{mg} \mathrm{L}^{-1}$ while vinegar and grape juice had lower anthocyanins as $1.70 \mathrm{mg} \mathrm{L}^{-1}$ and $0.15 \mathrm{mg} \mathrm{L}^{-1}$, respectively. Previously, total anthocyanin concentration was found to vary from 44.3 to $360.1 \mathrm{mg} \mathrm{L}^{-1}$ in wines (Arnous et al., 2002). Mazza et al. (1999) reported that variety, stages of fermentation and viticultural practices collection date seemed to be major factors influencing the relative concentrations of anthocyanins in wines.

\section{Conclusion}

As a conclusion, this paper shows that grape and grape products represent a potentially important source of the $\mathrm{CHO}$, minerals and phenolics; and there are quantitative differences in their composition depending on the sample types. Our data also suggest that grape is one of the most important fruits presenting the nutrients and valuable antioxidant compounds to people with different consumption types. To know compounds of these products plays a big role for people to gain a right consumption habit in daily diet.

\section{References}

Alonso AM, Castro R, Rodriguez MC, Guillén DA, Barroso, CG. 2004. Study of the antioxidant power of brandies and vinegars derived from Sherry wines and correlation with their content in polyphenols. Food Research International, 37: 715-721.

Anli RE, Vural N, Kizilet E. 2008. An alternative method for the determination of some of the antioxidant phenolics in varietal Turkish red wines. Journal of the Institute of Brewing, 114: 239-245.

Antoniolli A, Fontana AR, Piccoli P, Bottini R. 2015. Characterization of polyphenols and evaluation of antioxidant capacity in grape pomace of the cv. Malbec. Food Chemistry, 178: $172-178$ 
Aras Așcı Ö. 2020. Sağlıklı Yaşamda Üzüm ve Üzüm Ürünleri. Bilge International Journal of Science and Technology Research, 4 (Special Issue), 22-32.

Arnous A, Makris DP, Kefalas P. 2002. Correlation of Pigment and Flavanol Content with Antioxidant Properties in Selected Aged Regional Wines from Greece. Journal of Food Component and Analysis, 15: 655-665.

Babalık Z, Demirci T, Aşcı ÖA, Baydar NG. 2020. Brassinosteroids modify yield, quality, and antioxidant components in Grapes (Vitis vinifera cv. Alphonse lavallée). Journal of Plant Growth Regulation, 39: 147-156.

Balík J, Kumšta M, Rop O. 2013. Comparison of anthocyanins present in grapes of Vitis vinifera L. varieties and interspecific hybrids grown in the Czech Republic. Chemical Papers, 67: 1285-1292.

Bertoldi D, Larcher R, Bertamini M, Otto S, Concheri G, Nicolini G. 2011. Accumulation and distribution pattern of macro and micro elements and trace elements in Vitis vinifera L. cv. Chardonnay berries. Journal of Agricultural and Food Chemistry, 59: 7224-7236.

Bhat R, Kiran K, Arun AB, Karim, AA. 2010. Determination of mineral composition and heavy metal content of some nutraceutically valued plant products. Food Analysis Methods, 3, 181-187.

Bosanek CA, Silliman K, Kirk LL, Frankel EN. 1996. Total phenolic content and antioxidant potential of commercial grape juice. Journal of the American Dietetic Association, 96: A35.

Burin VM, Falcão LD, Gonzaga LV, Fett R, Rosier JP, Bordignon-Luiz MT. 2010. Colour, phenolic content and antioxidant activity of grape juice. Food Science and Technology, 30(4): 1027-1032.

Cantürk S, Kunter B, Aykut O, Keskin N. 2016. Gülüzümü’nün (Vitis vinifera $\mathrm{L}$.) mineral madde kompozisyonu ve tanedeki dağılımı. Bahçe, Special Issue: 45: 683-687.

Çetin ES, Babalık Z, Göktürk Baydar N. 2012. Bazı sofralık üzüm çeşitlerinde tanelerdeki toplam karbonhidrat, fenolik madde, antosiyanin, $\beta$-karoten ve $\mathrm{C}$ vitamininin belirlenmesi. IV. Ulusal Üzümsü Meyveler Sempozyumu Bildiri Kitabı, 03-05 Ekim 2012, Antalya, 151-158 pp.

Challacombe CA, Abdel-Aal ESM, Seetharaman K, Duizer LM. 2012. Influence of phenolic acid content on sensory perception of bread and crackers made from red or white wheat. Journal of Cereal Science, 56:181-188.

Champagnol F. 1998. Critéres de qualité de la vendange. Pp. $653-$ 659. In: Flanzy, C. (Ed). Oenologie, Fondements Scientifiques et Technologies. Lavoisier Tec and Doc, Paris.

Chiuve SE, Sun Q, Curhan GC, Taylor EN, Spiegelman D, Willett WC, Manson JE, Rexrode KM, Albert CM. 2013. Dietary and plasma magnesium and risk of coronary heart disease among women. Journal of the American Heart Association, 2: e000114.

Clegg DJ, Headley SA, Germain MJ. 2020. Impact of dietary potassium restrictions in CKD on clinical outcomes: Benefits of a Plant-Based Diet. Kidney Medicine, 2: 476-487.

Dai GH, Andary C, Mondolot L, Boubals D. 1995. Involvement of phenolic compounds in the resistance of grapevine callus to downy mildew (Plasmopara viticola). European Journal of Pant Pathology, 101: 177-188.

Davalos A, Bartolomé B, Cordovés CG. 2005. Antioxidant properties of commercial grape juices and vinegars. Food Chemistry, 93: 325-330.

Dawson-Hughes B, Harris SS, Palermo NJ, Castaneda-Sceppa C, Rasmussen HM, Dallal GE. 2009. Treatment with potassium bicarbonate lowers calcium excretion and bone resorption in older men and women. The Journal of Clinical Endocrinology and Metabolism, 94: 96-102.

De La Hera Orts ML, Martinez Cutillas A, Lopez Roca JM, Gomez Plaza E. 2005. Effect of moderate irrigation on grape composition during ripening. Spanish Journal of Agricultural Research, 3: 352-361.
Dharmadhikari M. 2010. Composition of Grapes. Iowa State University, Iowa State University Extension: Ames, Iowa.

Downey MO, Dokoozlian NK, Krstic MP. 2006. Cultural practice and environmental impacts on the flavonoid composition of grapes and wine: a review of recent research. American Journal of Enology and Viticulture, 57: 257-268.

Elmac1 Y, Altug T. 1993. Sugars in grape molasses: a comparison of Laneeynon and HPLC Method. Chemical Microbiology and Technology Lebensm, 15: 53-54.

El-Mashharawi HQ, Abu-Naser SS, Alshawwa IA, Elkahlout M. 2020. Grape Type Classification Using Deep Learning. International Journal of Academic Engineering Research, 3: 41-45.

Garcia Jahres CM, Lage-Yusty MA, Simal-Lozano J. 1990. Second derivative visible spectroscopic determination of iron and manganese in Galician wines. Fresenius' Journal of Analytical Chemistry, 388: 703-706.

Gil MI, Tomás-Barberán FA, Hess-Pierce B, Holcroft DM, Kader AA. 2000. Antioxidant activity of pomegranate juice and its relationship with phenolic composition and processing. Journal of Agricultural and Food Chemistry, 48: 4581-4589.

Gluba-Brzózka A, Franczyk B, Rysz J. 2017. Vegetarian diet in chronic kidney disease-A friend or foe. Nutrients, 9: 374.

Göktürk Baydar N, Babalık Z, Hallaç Türk F, Çetin ES. 2011. Phenolic composition and antioxidant activities of wines and extracts of some grape varieties grown in Turkey. Journal of Agricultural Sciences, 17: 67-76.

Göktürk Baydar N, Çetin S, Hallaç F, Babalık Z. 2005. Üzümlerde fenolik madde içeriklerinin spektrofotometrik yöntemlerle belirlenmesi, Cilt I. 329-334. VI. Bağcılık Sempozyumu Bildirileri, 19-23 Eylül 2005, Tekirdağ Bağcılık Araştırma Enstitüsü, Tekirdağ.

Göktürk Baydar N. 2006. Organic acid, tocopherol, and phenolic compositions of some Turkish grape cultivars. Chemistry of Natural Compounds, 42: 156-159.

Hallaç Türk F, Aras Ö, Babalık Z, Göktürk Baydar N. 2009. Kırmızı Üzüm Suyu ile Sirkenin Fenolik Bileşik İçerikleri ve Antioksidan Aktivitelerinin Belirlenmesi. Türkiye 7. Bağcılık Sempozyumu Bildiri Kitab1, 2: 247-253.

Hufnagel JC, Hofmann T. 2008. Orosensory-directed identification of astringent mouthfeel and bitter-tasting compounds in red wine. Journal of Agricultural and Food Chemistry, 56: 1376-1386.

Ivanova V, Stefova M, Chinnici F. 2010. Determination of the polyphenol contents in macedonian grapes and wines by standardized spectrophotometric methods. Journal of the Serbian Chemical Society, 75: 45-59.

Kanner J, Frankel E, Granit R., German B, Kinsella JE. 1994. Natural antioxidants in grapes and wines. Journal of Agricultural Food Chemistry, 42: 64-69.

Karakaya S, El SN, Tas AA. 2001. Antioxidant activity of some foods containing phenolic compounds. International Journal of Food Sciences and Nutrition, 52: 501-508.

Katalinic V, Milos M, Modun D, Music I, Boban M. 2004. Antioxidant effectiveness of selected wines in comparison with (+)-catechin. Food Chemistry, 86: 593-600.

Katalinic V, Smole Možina S, Skroza D, Generali'c I, Abramovič H, Miloš M, Ljubenkov I., Piskernik S, Pezo I, Terpinc P, Boban M. 2010. Polyphenolic profile, antioxidant properties and antimicrobial activity of grape skin extracts of 14 Vitis vinifera varieties grown in Dalmatia (Croatia). Food Chemistry, 119: 715-723.

Kavas A. 1990. Sağlıklı Beslenmede Kuru İncir Ve Çekirdeksiz Kuru Üzümün Önemi Semineri. İzmir Ticaret Odası, Tariş Bank Genel Müdürlüğü, Yayın No:1990/2, İzmir, 53-65 pp.

Kelebek H, Jourdes M, Selli S, Teissedre PL. 2013. Comparative evaluation of the phenolic content and antioxidant capacity of sun-dried raisins. Journal of the Science of Food and Agriculture, 93: 2963-2972. 
Keskin N, Yağc1 A, Kunter B, Cangi R, Sucu S, Altıncı NT. 2019. Mineral content of berries in native grape cultivars grown in Mid-Black Sea zone. Gaziosmanpasa Üniversitesi Ziraat Fakültesi Dergisi, 36: 220-229.

Khoo C, Falk M. 2014. Polyphenols in the prevention and treatment of vascular and cardiac disease, and cancer. Polyphenols in Human Health and Disease, 2: 1049-1065.

Konczak I, Zhang W. 2004. Anthocyanins - more than nature's colours. Journal of Biomedical Biotechnology, 5: 239-240.

Koundouras S, Marinos V, Gkoulioti A, Kotseridis Y, Leeuwen C. 2006. Influence of vineyard location and vine water status on fruit maturation of Nonirrigated Cv. Agiorgitiko (Vitis vinifera $\mathrm{L}$.). Effects on wine phenolic and aroma components. Journal of Agricultural Food Chemistry, 54: 5077-5086.

Li H, Wang X, Li Y, Li P, Wang H. 2009. Polyphenolic compounds and antioxidant properties of selected China wines. Food Chemistry, 112: 454-460.

Lopez A, Cacoub P, Macdougall IC, Peyrin-Biroulet L. 2016. Iron deficiency anaemia. The Lancet, 387(10021): 907-916.

Martins V, Cunha A, Gerós H, Hanana M, Blumwald E. 2012. Mineral compounds in grape berry. Pp. 23-43. In: Gerós H, Chaves MM, Delrot S. (eds). The Biochemistry of The Grape Berry. Bentham Science Publishers.

Mazza G, Francis FJ. 1995. Anthocyanins in grapes a nd grape products. Critical Reviews in Food Science and Nutrition, 35: 341-371.

Mazza G, Fukumoto L, Delaquis P, Girard B, Ewert B. 1999. Anthocyanins, phenolics, and color of Cabernet Franc, Merlot, and Pinot Noir wines from British Columbia. Journal of Agricultural Food Chemistry, 47: 4009-4017.

Mohammed FS, Karakaş M, Akgül H, Sevindik M. 2019. Medicinal properties of Allium calocephalum collected from Gara Mountain (Iraq). Fresen Environ Bull, 28(10): 7419-7426.

Mohammed FS, Pehlivan M, Sevindik E, Akgul H, Sevindik M, Bozgeyik I, Yumrutas O. 2021. Pharmacological properties of edible Asparagus acutifolius and Asparagus officinalis collected from North Iraq and Turkey (Hatay). Acta Alimentaria, 50(1): 136-143.

Mohammed FS, Şabik AE, Sevindik E, Pehlivan M, Sevindik M. 2020. Determination of Antioxidant and Oxidant Potentials of Thymbra spicata Collected from Duhok-Iraq. Turkish Journal of Agriculture-Food Science and Technology, 8(5): 1171-1173.

Nemzer BV, Kalita D, Yashin AY, Yashin YI. 2020. Bioactive compounds, antioxidant activities, and health beneficial effects of selected commercial berry fruits: A Review. Journal of Food Research, 9: 78-101.

Ojeda H, Andary C, Kraeva E, Carbonneau A, Deloire A. 2002. Influence of pre and postverasion water deficit on anthesis and concentration of skin phenolic compounds during berry growth of Vitis vinifera cv. Shiraz. American Journal of Enology and Viticulture, 53: 261- 267.

Orduña RM. 2010. Climate Change Associated Effects on Grape and Wine Quality and Production. Food Research International, 43: 1844-1855.

Özden M, Vardin H. 2009. Şanlıurfa Koşullarında Yetiştirilen Bazı Şaraplık Üzüm Çeşitlerinin Kalite ve Fitokimyasal Özellikleri. Harran Üniversitesi Ziraat Fakültesi Dergisi, 13: 21-27.

Panceri CP, Gomes TM, De Gois JS, Borges DLG, BordignonLuiz T. 2013. Effect of dehydration process on mineral content, phenolic compounds and antioxidant activity of Cabernet Sauvignon and Merlot grapes. Food Research International, 54: 1343-1350.

Pereira GE, Gaudillere JP, Pieri P, Hilbert G, Maucourt M, Deborde C, Moing A, Rolin D. 2006. Micro climate influence on mineral and metabolic profiles of grape berries. Journal of Agricultural and Food Chemistry, 54: 6765-6775.

Praznik W, Mundingler N, Kogler A, Uber P, Huber A. 1999. Molecular back- ground of technological properties of selected starches. Starch/Starke, 51: 197-211.
Price ML, Scoyos SV, Butler LG. 1978. A critical evaluation of the vanillin reaction as an assay for tannin in sorghum grain. Journal of Agricultural Food Chemistry, 26: 1214-1218.

Rababah TM, Al-u'datt M, Almajwal A, Brewer S, Feng H, AlMahasneh M, Ereifej K, Yang W. 2012. Evaluation of the nutraceutical, physiochemical and sensory properties of raisin jam. Journal of Food Science, 77: C609-C613.

Ribéreau-Gayon P, Glories Y, Maujean A, Duboirdeau D. 2000. Handbook of Enology, Volume 2: The Chemistry of Wine and Stabilization and Treatments, John Wiley and Sons Ltd., England, $450 \mathrm{pp}$.

Rovio S, Sirén K, Sirén H. 2011. Application of capillary electrophoresis to determine metal cations, anions, organic acids, and carbohydrates in some Pinot Noir red wines. Food Chemistry, 124: 1194-1200.

Sato Y, Nakanishi T, Wang L, Oishi K, Hirooka H, Kumagai H. 2020. In vitro and in vivo evaluations of wine lees as feeds for ruminants: Effects on ruminal fermentation characteristics, nutrient digestibility, blood metabolites and antioxidant status. Livestock Science, 241: 104217.

Sevindik M, Akgul H, Pehlivan M, Selamoglu Z. 2017. Determination of therapeutic potential of Mentha longifolia ssp. longifolia. Fresen Environ Bull, 26(7): 4757-4763.

Singleton VL, Rossi JR. 1965. Colorimetry of total phenolics with phosphomolybdic phosphotungstic acid. American Journal of Enology and Viticulture, 16: 144-158.

Soleas GJ, Diamandis EP, Goldberg DM. 1997. Wine as a biological fluid:History, production, and role in disease prevention. Journal of Clinical Laboratory Analysis. 11: 287313.

Sousa EC, Uchôa-Thomaz AM, Carioca JO, Morais SM, Lima A, Martins CG, Alexandrino CD. 2014. Chemical composition and bioactive compounds of grape pomace (Vitis vinifera L.), Benitaka variety, grown in the semiarid region of Northeast Brazil. Food Sci. Technol, Campinas, 34: 135-142.

Spiegel M, Andruniów T, Sroka Z. 2020. Flavones' and flavonols' antiradical structure-activity relationship-A quantum chemical study. Antioxidants, 9: 461.

Srilakshmi B. 2006. Nutrition Science, 2nd ed. New Age International Ltd. Publishers, Daryaganj, New Delhi, 936 pp.

Talwar GP, Srivastava LM. 2002. Textbook of Biochemistry and Human Biology. Prentice Hall of India Private Ltd., India, $1329 \mathrm{pp}$.

Toprak FE. 2011. Phytochemical characteristics in Kalecik Karasi grape cultivar (Vitis vinifera L.) grown in Ankara and Nevsehir. Ankara University, Graduate School of Natural and Applied Sciences M. Sc (Doctoral dissertation, Thesis, 64 pp.).

Üstün NS, Tosun I. 1997. Pekmezlerin Bileşimi. Gıda, 22: 303-307

Vrhovsek U, Mattivi F, Waterhouse AI. 2001. Analysis of red wine phenolics: comparison of HPLC and spectrophotometric methods. Vitis, 40: 87-91.

Watson KS, Boukhloufi I, Bowerman M, Parson SH. 2021. The relationship between body composition, fatty acid metabolism and diet in spinal muscular atrophy. Brain Sciences, 11: 131.

Wrostad RE. 1976. Color and pigment analysis in fruit product. Bulletin No. 624. Oregon Agricultural Experiment Station. Corvallis. OR.

Yang J, Martinson TE, Liu RH. 2009. Phytochemical profiles and antioxidant activities of wine grapes. Food Chemistry, 116: 332-339.

Yiğit EA, Yiğit Y. 2020. The effect of probiotic nutritions on health. TURAN-CSR International Scientific, 12: 339-345.

Zhang W, Furusaki S. 1999. Production of anthocyanin by plant cell cultures. Biotechnology and Bioprocess Engineering, 4: 231-252.

Zhang W, Iso H, Ohira T, Date C, Tamakoshi A, JACC Study Group. 2012. Associations of dietary magnesium intake with mortality from cardiovascular disease: the JACC study. Atherosclerosis, 221: 587-595. 